\title{
Histamine release by Western red cedar (Thuja plicata) from lung tissue in vitro
}

\author{
ELIZABETH EVANS AND P. J. NICHOLLS \\ Welsh School of Pharmacy, UWIST, Cardiff, CFI 3NU
}

\begin{abstract}
Evans, Elizabeth and Nicholls, P. J. (1974). British Journal of Industrial Medicine, 31, 28-30. Histamine release by Western red cedar (Thuja plicata) from lung tissue in vitro. Various respiratory symptoms have previously been observed in workers exposed to dust from Western red cedar (Thuja plicata). Although an allergic basis for these effects has been proposed, the possibility that the dust may contain a pharmacologically active agent was investigated. Aqueous extracts of two samples of red cedar released significant amounts of histamine from pig and human lung in vitro. For one of these samples, using pig lung, a dose-response relation was found over a narrow range of concentrations. These dusts possessed the same order of histamine-releasing activity as a sample of cotton dust. Potassium cyanide reduced the release of histamine caused by low concentrations of Western red cedar. Similar effects of cyanide on the histamine-releasing activity of cotton dust and compound $48 / 80$ were observed. It is possible that release of histamine in the lungs and upper respiratory tract occurs on inhalation of dust from Western red cedar and this may be a contributory factor to the development of respiratory symptoms in workers exposed to the dust of this wood.
\end{abstract}

Respiratory symptoms following exposure to dust of Western red cedar (Thuja plicata) were briefly described by Doig (1949), who reported two minor episodes of asthma among men working with this wood. The respiratory syndrome resulting from exposure to Western red cedar has been reported in detail more recently by Gandevia and Milne (1970) and Chan-Yeung, Barton, McLean, and Grzybowski (1971). These authors describe the gradual development of dry irritating cough and chest tightness throughout the working day accompanied by nocturnal attacks of cough and wheeze. In a small number of cases there was an immediate asthmatic reaction on inhalation of dust or dust extracts, and some individuals experienced rhinitis of varying severity. Partial or complete recovery was observed during weekends or holidays.

Positive bronchial reactions, measured as a small but significant decrease in the forced expiratory volume at one second $\left(\mathrm{FEV}_{1 \cdot 0}\right)$, were observed in men working exclusively with this timber (Gandevia, 1970) and were also seen in response to provocative in- halation of extracts of cedar dust (Gandevia and Milne, 1970). While it is thought that the basis of the asthmatic responses is allergic in nature (Chan-Yeung et al., 1971), Gandevia (1970) has suggested that the most likely interpretation of the changes in ventilatory capacity found in the Western red cedar workers is that they reflect a non-specific bronchial reaction to inhaled particulate matter.

It is possible that other mechanisms may also be involved in the production of these respiratory symptoms. Since histamine-releasing activity has been detected in certain wood dusts such as the tropical woods, ukola and okumen, which cause rhinitis, wheezing, and eye irritation (Subiza, Alizo, and Diaz, 1970), it was of interest to examine whether Western red cedar possessed pharmacological activity of this type.

\section{Materials and methods}

Two samples of Western red cedar were examined. Sample A was from a carpenter's workshop in Australia 
and was provided by Dr. B. Gandevia. Sample B was obtained from the workshop of the Welsh School of Pharmacy. These samples consisted of sweepings from benches and floors. Both samples were ground mechanically to a moderately coarse powder (22/60; British Pharmacopoeia, 1968). Airborne cotton dust was collected from a Lancashire mill spinning a coarse grade of cotton. The synthetic histamine releaser, compound $48 / 80$, was purchased from the Wellcome Research Laboratories, Beckenham, Kent.

Aqueous extracts of the dusts were prepared by grinding the material $(3 \mathrm{~g})$ with Tyrode solution $(18 \mathrm{ml})$ in a mortar for 15 minutes. After filtration through cotton gauze, the extracts were centrifuged at $1000 \mathrm{~g}$ for 15 minutes. The supernatant was adjusted to $\mathrm{pH} 7.4$ and the volume was made up to $18 \mathrm{ml}$ with Tyrode solution. Compound 48/80 was dissolved in Tyrode solution.

Pig lung was obtained from the local abattoir and macroscopically normal human lung was obtained from surgical lung resections. In all cases, the lung was immediately placed in Tyrode solution at $4^{\circ} \mathrm{C}$ until it was prepared for the incubation experiments two to three hours later.

The histamine-releasing activity of the extracts was determined according to the procedure of Nicholls, Nicholls, and Bouhuys (1967). Chopped lung (100 mg) was incubated with various amounts of either the dust extracts, compound $48 / 80$ or Tyrode solution at $37^{\circ} \mathrm{C}$ for 25 minutes. The final volume was $3 \mathrm{ml}$. At the end of incubation histamine released into the medium was determined spectrophotofluorimetrically (Shore, Burkhalter, and Cohn, 1959). For each lung specimen employed, the histamine content was also determined by this method.

Glucose-free Tyrode solution was employed for experiments in which potassium cyanide $\left(\mathrm{KCN}, 10^{-3} \mathrm{M}\right)$ was used. The KCN in Tyrode solution was incubated with the lung for 15 minutes before addition of either the dust extracts or compound $48 / 80$.

\section{Results}

Extracts of both samples of Western red cedar released histamine from human and pig lung in vitro (Table). In both species, the activity of these extracts was of the same order as an extract of cotton dust prepared from an equivalent amount of material. The effect of compound $48 / 80$ is included for comparison, and it is evident that this substance is a potent histamine releaser in human and pig lungs.

Using pig lung, a dose-response relation was shown for cotton dust over the concentration range 5-80 $\mathrm{mg} / \mathrm{ml}$. Compound $48 / 80$ also possessed an effect that was related to its concentration. Dose-related effects for cedar wood were clearly observed only in the narrow range of $5-10 \mathrm{mg} / \mathrm{ml}$ (Table).

The effect of the metabolic inhibitor, $\mathrm{KCN}$, upon histamine release from pig lung was studied in order to indicate whether energy-dependent mechanisms in the lung were involved in the action of cedar and cotton dusts. It may be seen that the inclusion of $\mathrm{KCN}$ $\left(10^{-3} \mathrm{M}\right)$ in the incubation medium reduced the
T ABLE

Histamine Release from Lung Tissue in vitro

\begin{tabular}{|c|c|c|c|c|}
\hline \multirow{3}{*}{ Material } & \multirow{3}{*}{$\begin{array}{l}\text { Concen- } \\
\text { tration } \\
(m g / m l)\end{array}$} & \multicolumn{3}{|c|}{ Histamine released $(\%)^{2}$} \\
\hline & & \multirow{2}{*}{$\begin{array}{c}\text { Human } \\
\text { lung }^{3}\end{array}$} & \multicolumn{2}{|c|}{ Pig lung } \\
\hline & & & No KCN & $K C N^{5}$ \\
\hline $\begin{array}{l}\text { Western red cedar } \\
\text { Sample A } \\
\text { Sample B }\end{array}$ & $\begin{array}{r}80 \\
5 \\
10 \\
25 \\
50 \\
80 \\
100\end{array}$ & $5 \cdot 8$ & $\begin{array}{l}6 \cdot 7 \\
2 \cdot 3 \\
5 \cdot 9 \\
5 \cdot 4 \\
6 \cdot 3 \\
6 \cdot 1 \\
6 \cdot 4\end{array}$ & $\begin{array}{l}1 \cdot 0 \\
3.7\end{array}$ \\
\hline Cotton dust & $\begin{array}{r}5 \\
10 \\
25 \\
80\end{array}$ & $9 \cdot 1$ & $\begin{array}{l}1 \cdot 4 \\
3 \cdot 3 \\
5 \cdot 0 \\
7 \cdot 4\end{array}$ & $\begin{array}{l}0.9 \\
2.5\end{array}$ \\
\hline Compound $48 / 80$ & $\begin{array}{l}0.01 \\
0.03 \\
0.5\end{array}$ & $11 \cdot 2$ & $\begin{array}{r}5 \cdot 5 \\
7 \cdot 0 \\
31 \cdot 0\end{array}$ & $2 \cdot 9$ \\
\hline
\end{tabular}

Chopped lung (100 mg) was incubated in Tyrode solution $(3 \mathrm{ml})$ for 25 minutes at $37^{\circ} \mathrm{C}$. Histamine liberated into the incubation medium was assayed fluorimetrically.

'final concentration in incubation medium; this represents the soluble fraction from the weight of material listed;

${ }^{2}$ histamine released expressed as $\%$ of the total histamine in the lung sample $(100 \mathrm{mg})$;

${ }^{3}$ results are the means of duplicate determinations from one lung sample;

'results are means from three experiments;

${ }^{5} \mathrm{KCN}\left(10^{-3} \mathrm{M}\right)$ present in incubation mixture.

histamine released by both dusts and compound 48/80 (Table).

\section{Discussion}

On a weight basis, the two samples of Western red cedar possess about the same degree of histaminereleasing activity as the cotton dust sample examined. There is evidence that inhalation of this cotton dust by normal human subjects causes the release of histamine (Edwards et al., 1970). Therefore, it is possible that cedar wood dust may release histamine from the lungs following inhalation by workers exposed to the dust, and this could contribute to the development of respiratory symptoms. Because the decreases in ventilatory capacity observed in subjects exposed to cedar dust were relatively inconsistent in the most heavily exposed workers (Gandevia, 1970 ), the presence of a pharmacologically active bronchoconstrictor substance in the dust was thought to be unlikely. However, it should be noted that intersubject variation in response to an inhaled histamine releaser is to be expected as it will depend upon $(a)$ the histamine content of the lung, (b) the releasability 
of histamine from its stores in the lung tissue, and (c) the sensitivity of the bronchial muscle to the released histamine, all of which are probably independent variables (Nicholls et al., 1967).

Various metabolic inhibitors, including cyanide, reduce the release of histamine from mast cells by compound 48/80 (Mota and Ishii, 1960; Uvnäs and Thon, 1961) and this has been interpreted as demonstrating the involvement of an energy-dependent mechanism in the action of this histamine releaser. As it has been shown that histamine release from mast cells by compound $48 / 80$ is difficult to block by metabolic inhibitors when the releaser is acting at high concentrations (Yamasaki and Endo, 1967), the effect of KCN upon the activity of the dusts was examined only at low concentrations of the latter. The reduction in the histamine released by cedar and cotton dust extracts in the presence of $\mathrm{KCN}$ indicated that cellular respiration or an energy-dependent process may be essential for the activity of these agents.

Further studies of the histamine-releasing activity of Western red cedar would be of interest. In particular, the isolation and purification of the active agent would enable definitive provocative tests to be performed which would establish what respiratory effects, if any, are due to the release of histamine when cedar dust is inhaled. The histamine-releasing activity present in Ukola wood (Subiza et al., 1970) is associated with the saponin fraction. This is unlikely to be so for cedar wood because of the results with $\mathrm{KCN}$. Saponins are surface-active agents and probably release histamine by a physicochemical mechanism which would not be inhibited by KCN (Mongar and Schild, 1957).

Other pharmacological properties of constituents in cedar wood may also be of importance in determining the respiratory effects seen after inhalation of the dust. It is of interest that tropolones, which form the major portion of the volatile fraction of Western red cedar (Chan-Yeung et al., 1971), possess $\beta$-adrenoreceptor antagonist activity (Belleau and Burba, 1963). Such antagonists are potentially capable of altering the balance between vagal and sympathetic stimuli reaching airway smooth muscle and, therefore, of altering smooth muscle sensitivity. Indeed, it has been shown that small doses of propranolol, administered orally, potentiate the effects of a histamine aerosol as well as the response to inhalation of hemp dust in man (Bouhuys, 1971).

However, it should be noted that Canadian red cedar is almost unique in causing delayed attacks of breathlessness which may occur on several successive nights following one inhalation by some sensitized individuals (Gandevia, 1970; Chan-Yeung et al., 1971). This cannot be directly due to histamine release and it is difficult to attribute it to $\beta$-receptor blocking activity until more is known about the pharmacological activity and fate of the cedar wood tropolones following inhalation.

We wish to thank Dr. B. Gandevia for a sample of Western red cedar dust. P.J.N. is in receipt of a grant from the Medical Research Council.

\section{References}

Belleau, B. and Burba, J. (1963). Occupancy of adrenergic receptors and inhibition of catechol-0-methyl transferase by tropolones. Journal of Medicinal Chemistry, 6, 755-759.

Bouhuys, A. (1971). Byssinosis: airway responses caused by inhalation of textile dusts. Archives of Environmental Health, 23, 405-407.

British Pharmacopoeia (1968). p. 1372. Pharmaceutical Press, London.

Chan-Yeung, M., Barton, G. M., McLean, L., and Grzybowski, S. (1971). Bronchial reactions to Western red cedar (Thuja plicata). Canadian Medical Association Journal, 105, 56-59.

Doig, A. T. (1949). Other lung diseases due to dust. Postgraduate Medical Journal, 25, 639-649.

Edwards, J., McCarthy, P., McDermott, M., Nicholls, P. J., and Skidmore, J. W. (1970). The acute physiological, pharmacological and immunological effects of inhaled cotton dust in normal subjects. Journal of Physiology, 208, 63P.

Gandevia, B. (1970). Ventilatory capacity during exposure to Western red cedar. Archives of Environmental Health, 20, 59-63.

and Milne, J. (1970). Occupational asthma and rhinitis due to Western red cedar (Thuja plicata), with special reference to bronchial reactivity. British Journal of Industrial Medicine, 27, 235-244.

Mongar, J. L. and Schild, H. O. (1957). Inhibition of the anaphylactic reaction. Journal of Physiology, 135, 301-319.

Mota, I. and Ishii, T. (1960). Inhibition of mast cell disruption and histamine release in rat anaphylaxis in vitro. Comparison with compound 48/80. British Journal of Pharmacology and Chemotherapy, 15, 82-87.

Nicholls, P. J., Nicholls, G. R., and Bouhuys, A. (1967). Histamine release by compound 48/80 and textile dusts from lung tissue in vitro. In Inhaled Particles and Vapours, II: Proceedings of an International Symposium, Cambridge, 1965 , edited by C. N. Davies, pp. 69-74. Pergamon, Oxford.

Shore, P. A., Burkhalter, A., and Cohn, V. H. (1959). A method for the fluorimetric assay of histamine in tissues. Journal of Pharmacology and Experimental Therapeutics, 127, 182-186.

Subiza, E., Alizo, P., and Diaz, P. (1970). Estudios experimentales del contenido en histamina ye efecto histaminoliberador del Sisal, Bagazo, Canamo, Algodon y Madera de Ukola (Dumoria Africana). Proceedings of Second International Conference on Respiratory Diseases in Textile Workers, Alicante, Spain, 30 September to 2 October, 1968, pp. 110-127.

Uvnäs, B. and Thon, I. (1961). Evidence for enzymatic histamine release from isolated rat mast cells. Experimental Cell Research, 23, 45-57.

Yamasaki, H. and Endo, K. (1967). Coexistence of energy dependent and non-dependent processes in histamine release mechanism of compound $48 / 80$ and sinomenine: Experiments on chopped skin from various animal species. Japanese Journal of Pharmacology, 17, 228-239

Received for publication May 11, 1973

Accepted for publication August 14, 1973 